\title{
高齢者のための住宅改修における職種間の連携に関する研究 A STUDY ON COOPERATION AMONG OCCUPATIONS OF HOUSE ADAPTATION FOR ELDERLY-PEOPLE
}

\author{
金 東 淑 ${ }^{* 1}$, 大原一興*2 \\ Dongsook KIM and Kazuoki OHARA
}

\begin{abstract}
The purpose of this study was to clarify the actual situation about cooperation among occupation that wrestles with house adaptation for elderly-people with four cooperations around Tokyo.The results are

1,The motivation of participation to organization of among occupation is social situation .

2, An effect by cooperation among occupation is left in peace each other. However there is problems that whole care cannot be seen etc.

3,As for the information for the physical situation of elderly people, there are lots of cases passed to designers / Construction contractors / of welfare house environment coordinators from home helpers or care managercontractors, welfare living environment Coordinators in many cases.
\end{abstract}

4,The information of physical situation and past cases of elderly people is important.

Keywords : Houseadaptation,elderly-people,specialist,cooperation among occupations 住宅改修、高齢者、専門家、職種間の連携

\section{1 研究の背景と目的}

日本は、本格的な高齢社会の到来とともに、在宅高齢者の 介護や自立生活の重要性がますます高まっている。特に、 1990 年代以降に施設福祉より在宅福祉へと転換期を向え、医 療・保健・福祉・建築（以下：職種）の連携注1)による高齢者 のための住宅改修が注目されるようになった。このため、高 齢者に適応した住環境改善を目的亡する在宅ケアのサポート が重要視され、職種の連携による住宅改修の組織・団体の活 動が各地域で広がっている。その職種の連携による主な活動 としては、勉強会や研究会の開催、各専門家が相互間の情報 収集や知識の交換などが行なっている。

しかし、このような職種の連携による参加活動は、いずれも 専門家毎の自由参加による構成が多く、住宅改修を取り組む際 の関わり方、情報収集のプロセス、専門家の確保や相互の関連 性などによるトラブルが大きな課題となっている。これらの課 題を踏まえての、専門職による住宅改修への取り組みと意識文 1、2、3、5、11、12)、職種による住宅改修への支援のあり方文:9、10) など に関する研究は多少あるが、職種の組織の実態に関する研究は 見当たらない。さらに、各専門家が連携に取り組む際の関わり 方、参加頻度、連携による効果などに対して、その結果を明
らかにされた研究は少ない。

そこで、本研究では、高齢者のための住宅改修注2)に取り組ん でいる職種の連携組織における専門家注3) の意識調査をもとに 考察を行なう。すなわち、(1)職種の連携組織への加入経由や年 数、活動の現状や研究会の参加動向、(2)職種の連携における効 果や問題点、(3)専門家間の情報の流れや求めている情報などに 対する意識を明らかにし、実態の把握と問題点を析出し、今後 の方向性を提示することを目的としている。

\section{2 研究の対象と方法}

高齢者の在宅生活をサポートするために、住宅改修に先進的 に取り組んでいるさまざまな団体・組職やネットワークが全国 的に存在している。これらの概要を見ると、立ち上げる動機や 活動の体制などはそれぞれ異なっているが、高齡者の地域での 居住継続をサポートし、介護、住宅改修などの居住生活に必要 な精神的・物理的な支援と共に、その組職に属している専門家 に専門知識や技術・経験などの水準を上げることの目的は類似 している。このような組織は、現在も増え続けており、研究会 レベルのネットワークも含めると数多くの団体・組織が高齝者 の地域生活を支えている。

*1 横浜国立大学大学院 博士後期

*2 横浜国立大学大学院工学研究院 教授. 工博 
本研究では、職種の連携組織の中でも高齢者のための住宅改 修に取り組んでいる東京周辺の 4 つの組織を対象に調查を行な いその中に属している各職種の専門家に着目した。回答紙に は 2 つ以上の職業を持っている専門家もいるが、この論文では 職種による違いや職種閒の連携の情報の流れを考察するため以 降は、別々の専門家として集計した。

4 つの組織（表 1）の専門家を対象に、ヒアリング調査（2003 年 7 月〜 9 月） と郵送（2003 年 10 月 7 日〜 30 日）によるアン ケート調査を行なった。郵送による配布数は 220 通、回収率は $42.2 \%$ (93 通) であり、職種別分析に用いたデー夕の総数は 118 通で、分析方法としては、クロス集計に加えてサーストン の一対比較法を用いた。

\begin{tabular}{|c|c|c|c|c|c|}
\hline 連拹名 & |設立年 & $\begin{array}{c}\text { 会員数 } \\
\text { (回答者数) } \\
\end{array}$ & 活動攵点 & 組織等 & 活動内容 \\
\hline A団体 & 1995 & $35(30)$ & 町田 & NPO & $\begin{array}{l}\text { 事例検討会、定例会、 } \\
\text { 見学会、相談など } \\
\end{array}$ \\
\hline B団体 & 1994 & $52(17)$ & 渋谷 & 民間団体 & $\begin{array}{l}\text { 事例の検討や研 } \\
\text { 究、相談など } \\
\end{array}$ \\
\hline c団体 & 1997 & $27(10)$ & 板橋 & 民間団体 & $\begin{array}{l}\text { 定例会、相談、参 } \\
\text { 加型体験学習など } \\
\end{array}$ \\
\hline D団体 & 1999 & $106(36)$ & 平塚 & NPO & $\begin{array}{l}\text { 勉強会、住まい } \\
\text { うくりの支援など }\end{array}$ \\
\hline
\end{tabular}

\section{3 調査対象の属性}

職種間の連携組織に扮ける属性を表 2 に示す。調査対象の年 齢は 50 代が $39.8 \%$ 、次に 30 代が $22.9 \%$ である。職種別では、 建築が $42.4 \%$ 、福祉が $34.7 \%$ 、医療・保健が $11.0 \%$ である。さ らに、表 3 に示した専門家の分布では、医療・保健の OT (作業 療法師)、P T （理学療法士）が非常に少なく、職種の連携にお いて専門家の分布に偏りがみえた。また、兼任の職業として多 い専門家としては、看護師のケアマネージャーと設計士・施工 業者・工務店の福祉住環境コーディネーターである。

表 2 基本的属性

\begin{tabular}{|c|c|c|c|c|c|c|}
\hline & & & & & 単位： & 呚 (\%) \\
\hline \multirow{2}{*}{ 年齡 } & 20 代 & 30 代 & 40 代 & 50 代 & 60 代 & 70代 \\
\hline & $4(3.4)$ & $27(22.9)$ & $25(21.2)$ & $47(39.8)$ & $11(9.3)$ & $1(0.8)$ \\
\hline \multirow{2}{*}{ 性別 } & \multicolumn{2}{|c|}{ 男性 } & \multicolumn{2}{|c|}{ 女性 } & \multicolumn{2}{|c|}{ 合部 } \\
\hline & \multicolumn{2}{|c|}{$60(50.8)$} & \multicolumn{2}{|c|}{$58(49.2)$} & \multicolumn{2}{|c|}{$118(100)$} \\
\hline \multirow{2}{*}{ 聖 } & 医潦·保健 & 福祉 & 建築 & その他 & \multicolumn{2}{|c|}{ 合婛 } \\
\hline & $13(11.0)$ & $41(34.7)$ & $50(42.4)$ & $14(11.9)$ & \multicolumn{2}{|c|}{$118(100)$} \\
\hline \multirow{2}{*}{ 団体別 } & 町田 & 涉谷 & 板橋 & 平塚 & \multicolumn{2}{|c|}{ 合㹁 } \\
\hline & $33(28.0)$ & $25(21.2)$ & $12(10.2)$ & $48(40.7)$ & \multicolumn{2}{|c|}{$118(100)$} \\
\hline
\end{tabular}

\section{4 高齢者のための住宅改修における職種の概要}

職種における高齢者のための住宅改修の実績（表 3) は、医療 · 保健は、 $21 \sim 50$ 件が 6 人、福祉は 20 件以下が 27 人、建築は 20 件以下が 18 人で、各職種とも 50 件以下の経験が最も多く、高 齢者のための住宅改修の経験は多い人は少ないといえる。ま た、専門家別でも多く関わった件数が 20 件を超えることはな く、福祉住環境コーディネーターが 11 人で最も多く示してお り、施工業者・工務店が 10 人、設計士やケアマネージャーが 各 8 人の順に関わっている。

住宅改修の工事金額は、図 1に示したように、11〜20 万円が 42 人で最も多く、次いで、 $21 \sim 50$ 万円が 41 人で、結果として、 $11 \sim 50$ 万円に集中している。51万円以上の工事は比較的に少
なく、高齢者のための住宅改修の工事は大規模な工事よりも小 規模な工事が多い。その原因として考えられるのは、2000 年 4 月から実施された介護保険での住宅改修の支給対象金額上限が 20 万円であることの影響が大きいと推測されるが、実際には、 これらの職種がかかわる場合には、20 万円を越える工事も少な くない。

表 3 各専門家の属性概要

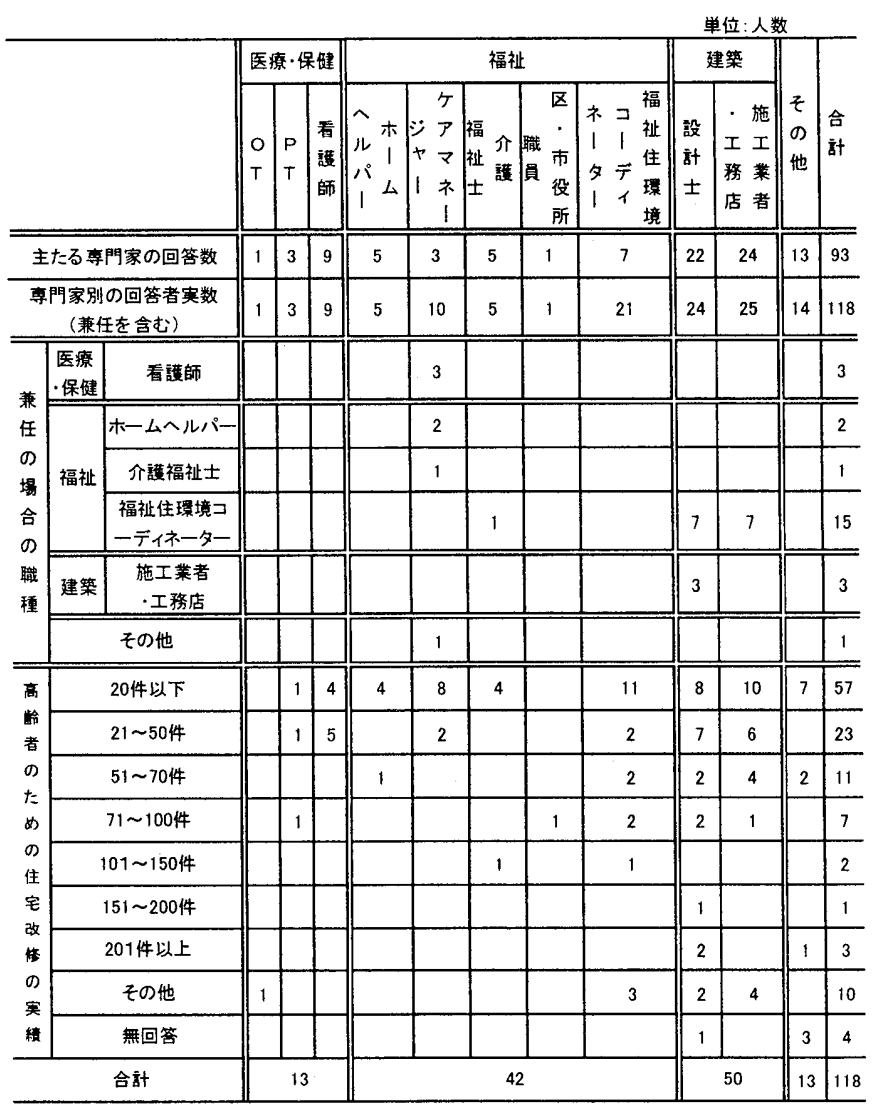

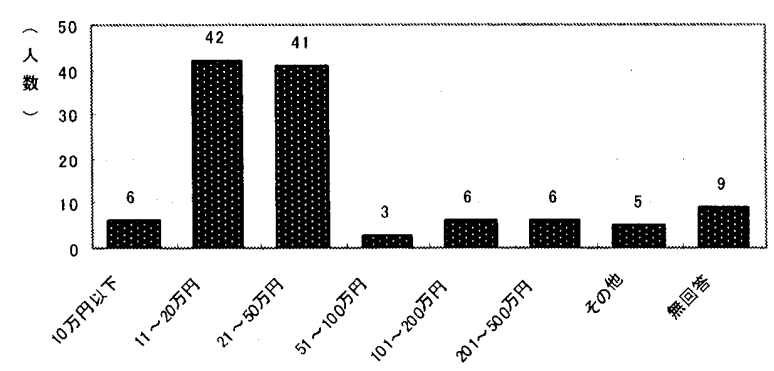

図 1 工事金額

\section{5 各職種の連携における活動動向と意識 5.1 各職種の連携への参加の動機}

職種の連携組織への参加の動機はさまざまであったが、ヒア リング調査で明らかになった幾つかの動機を基にアンケート調 查を行った。その動機付けの結果を図 2 に示す。医療・保健・ 福祉は、「社会貢献のため」、建築は「社会的な流れで」が最も 多い動機であった。この 2 つの理由を合わせると半数以上を占 め、多くの専門家が地域社会の連携や高齢社会に対して意識を 高くもっていることが読み取れる。

また、各職種の連携組織における職種の参加年数（図３）を 
みると、職種毎の大きな差異は見られないが、医療・保健では $3 \sim 4$ 年、福祉と建築が $1 \sim 2$ 年で連携での参加が多く見られた。 全体的には $3 \sim 4$ 年が 3 割で最も多く、1 年末満から 4 年まで 7 割以上を占めており、1 4 年の間に参加者が增えている。こ の結果は、2000 年 4 月から開始された介護保険制度が 4 年に 経っていることから、ほとんどの場合が介護保険制度ととも に、連携組織に参加したものと推測される。また、 4 年未満で 新たに加わった専門家としては、介護保険制度の介護支援専門 員であるケアマネージャーと多職種の連携での中間的な役割と して注目されている福祉住環境コーディネーター注4)の参加の 増加による結果であると考えられる。また、これらの専門家 は、今後の高齢者のための住宅改修における役割に大きな期待 が寄せられている。
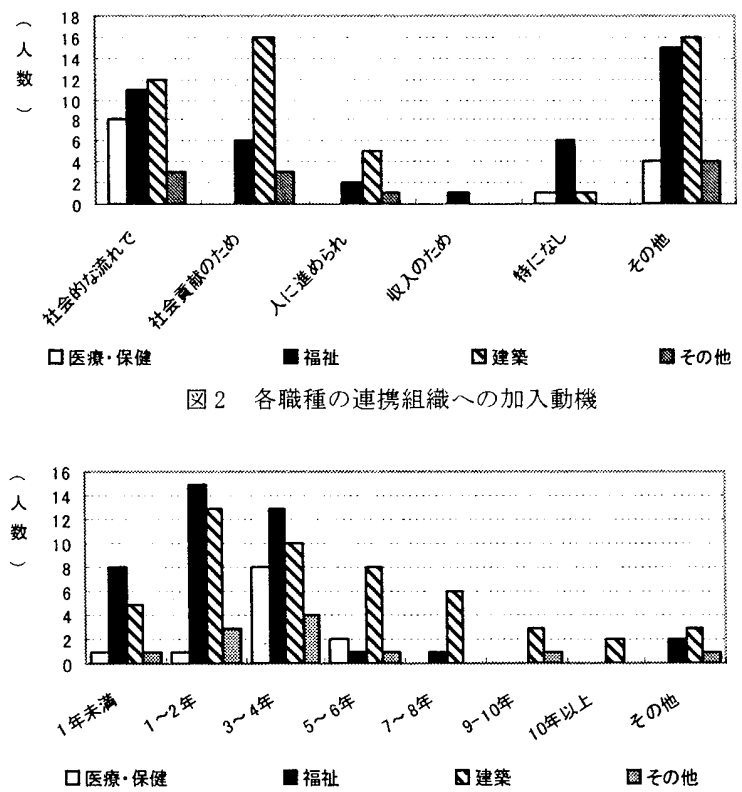

図 3 各職種の連携組織への参加年数

連携組織の主な活躍の一つである研究会での専門家の参加状 況による参加回数を図 4 に示す。組織毎の研究会の開催回数は 異なっているものの、一般的に毎月 $1 \sim 2$ 回程度が行われてい る。研究会の主な目的は、過去の事例検討や新しい制度への対 応、職種間の情報交流などである。連携での研究会に参加回数 は、全体的に「ほぼ每回」が 4 割を占めている。詳細にみると 医療・保健が「2、3 ケ月に 1 回」、福祉・建築は「ほぼ毎回」が 最も多かったが、それぞれの職種においても、「ほぼ毎回」、「2、

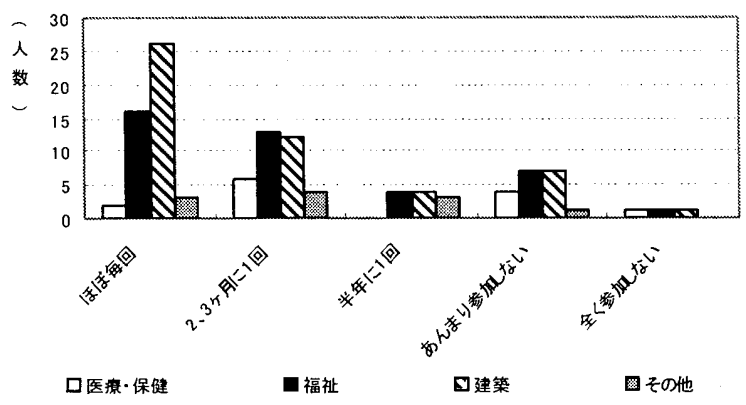

図 4 職種の研究会の参加回数
3 ケ月に 1 回」の回数で研究会に参加している専門家が多くみ られ、比較的に高い参加を示している。

図 5 は、住宅改修に取り組む際に、参考としている資料（以 下：参考資料）と連携組織の研究会の参加動向を多種ク口ス集 計したものである。すなわち、職種間の連携組織の活動による 高齢者のための住宅改修に対する効果を問う項目である。「ほ ぼ毎回」と回答した専門家が、すべての項目で参考資料を多く 得ている。その詳細な内容をみると、高齢者と家族により得ら れる参考資料としては「高㱓者本人や家族の意見小、研究会の 参加により得られる資料としては、「各職種との情報交流」、 「連携での事例検討会」、「過去の事例」であり、「ほぼ毎回」と 回答した専門家が最も多い参考資料を得ていることが分かる。 これらの結果は、研究会の参加率が高い職種ほど、住宅改修に 取り組む際に研究会の活動（情報交換や参考資料）が役に立つ 資料として効果があると考えられる。

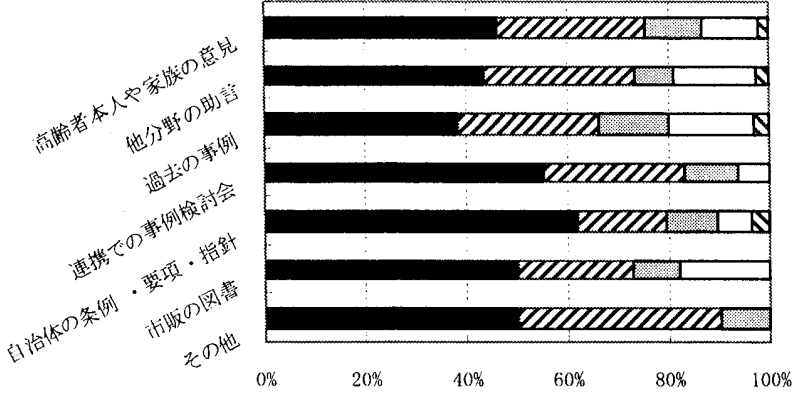

口ほほ毎回日2,3ヶ月に间 圆半华に间口あまり参加しない区全く参加しない

図 5 職種の連携での研究会の参加動向と参考資料との関係

\section{2 利用者ニーズへの対応}

住宅改修に取り組む際に高齢者の身体状況や居住環境を把握 寸るために事前調査が必要であり、訪問による正確な現況の把 握の上で適切な対応をしなければならない。しかし、適切な訪 問頻度の決まりはなく、それぞれ専門家の個人差がある。図 6 に示した各職種の利用者への訪問頻度の結果をみると職種にか かわらず、全体的な動向として、1〜2 回の訪問が多く、次に

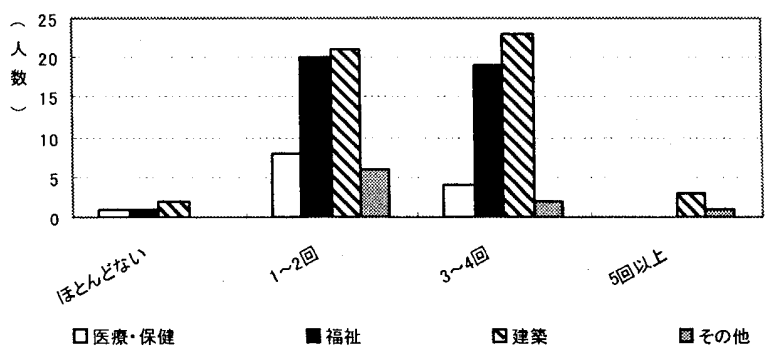

図 6 各職種の利用者への訪問頻度

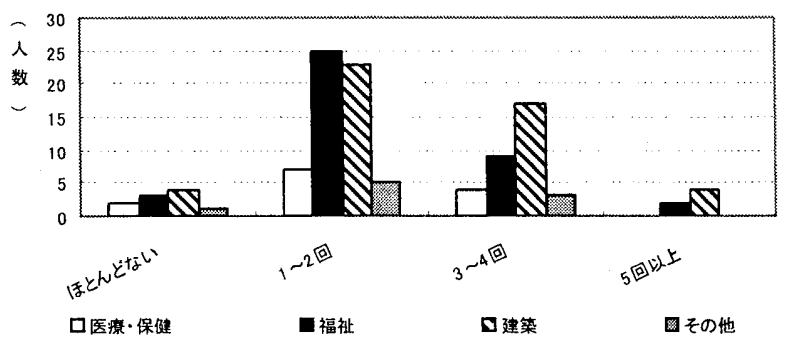

図 7 職種間の情報交換頻度 
$3 \sim 4$ 回の訪問を行っている。また、図 7 に示した職種間の情 報交換頻度は $1 \sim 2$ 回が最も多く、次に $3 \sim 4$ 回が多く占めて いる。

上記の結果をまとめると、連携に加入しているほとんどの職 種が利用者への訪問や職種間の情報交換の場を $1 \sim 4$ 回の頻度 で行ないながら、住宅改修に取り組んでいる。

さらに、これらの情報交換の手段を詳細に示したものが表 4 である。その特徵として、「各専門家が集まって」が 54 人で最 も多く、次に「電話で」が 35 人を占め、これらの二つの方法 により相互間の主な情報交換を行っている。

表 4 職種間の情報交換の方法

\begin{tabular}{|c|c|c|c|c|c|c|}
\hline & & & & & \multicolumn{2}{|c|}{ 單位: 人数 } \\
\hline & & 医癔·保健 & 福祉 & 建築 & その地 & 合部 \\
\hline \multirow{2}{*}{$\begin{array}{l}\text { 情 } \\
\text { 報 }\end{array}$} & 各央門家が果まって & 6 & 17 & 27 & 4 & 54 \\
\hline & 電話で & 4 & 13 & 13 & 5 & 35 \\
\hline \multirow{2}{*}{ 交 } & メールた & - & 1 & - & 1 & 2 \\
\hline & 童類で & 2 & 6 & 4 & - & 12 \\
\hline 方 & その地 & - & 2 & 6 & - & 8 \\
\hline \multirow[t]{2}{*}{ 法 } & 無回答 & 1 & 2 & - & 4 & 7 \\
\hline & 合計 & 13 & 41 & 50 & 11 & 118 \\
\hline
\end{tabular}

\section{3 高齢者のための住宅改修における職種別の意識}

ここでは高齢者のための住宅改修において職種間の連携が専 門家に与えている意識を示したものである。図 8 で見られるよ うに職種の連携において不安感に対する意識としては、職種別 に大きな違いはないが、すべての項目で同様な傾向がみられ た。まず、高齢者の身体状況や居住環境に対する適切な処置に よる自分自信が抱えている不安感 ( $a, b, g)$ が高く、仕事に対 する不安感 (d) は低い。次に、建築での「仕事が減った時」(d) に対する不安感が非常に低いことや医療での「要介護者にとっ て適切な処置をしたかどうかで悩む時」、「高齢者在宅ケアに関 する知識の不足を感じる時」（a,f）に対する不安感が他職種に 比べて高い数値を占めした。

図 9 は、職種の連携による効果を示したものである。「他職種 の知識が身につく、、仕事が増える」の項目では、医療・保健 が他職種に比べて低い数值を占めていることに対して、「他職 種との情報が取りやすい」の項目では、その他が他職種に比べ て非常に高い意識を持っており、すべての項目において、高い 意識を占めている。ここでの「その他」の専門家としては組織 の事務員としての人やアドバイザなどである。さらに、「仕事 が増える」の項目は、全体的な評価が低く、連携において住宅 改修の仕事が增えることは少ない。仕事があっても経済的な効 果には結びつくほどの状況ではない。むしろ連携での仕事は、 ボランティア精神に基づいて地域の高㱓者が住みやすくするた めに住宅改修を行なっていることが、ヒアリング調査から明ら かになった。

\section{6 高齢者の身体状況に関する情報の流れ}

\section{1 高柃者の身体状況に関する最も情報を得やすい職種}

職種間において、高齢者の身体状況に関する情報の流れを表 5 に示めした。その結果として、医療・保健は「高齢者本人・ 家族」に情報が得やすいとの回答が 7 人で最も多く、次いで同 職種である「医療・保健」が 2 人である。また、建築は情報を

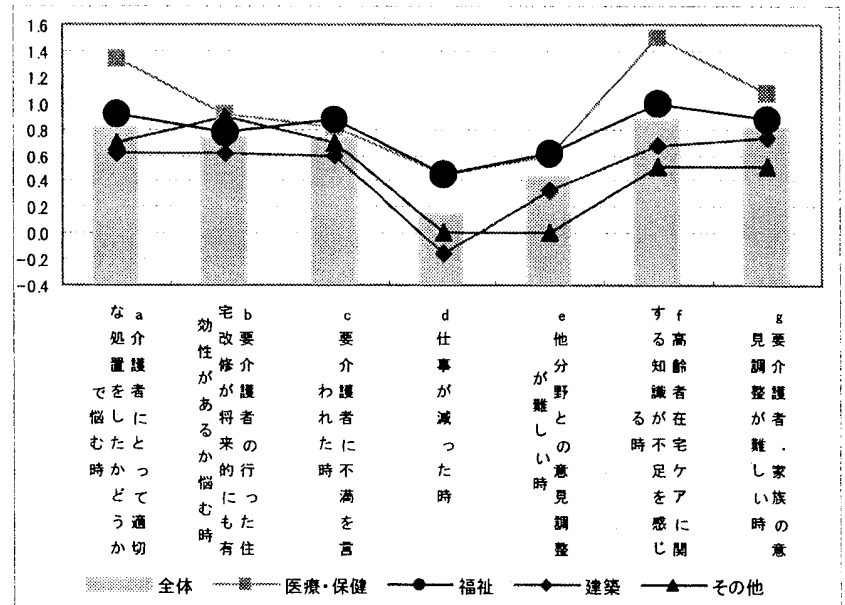

図 8 各職種の不安感に対する意識

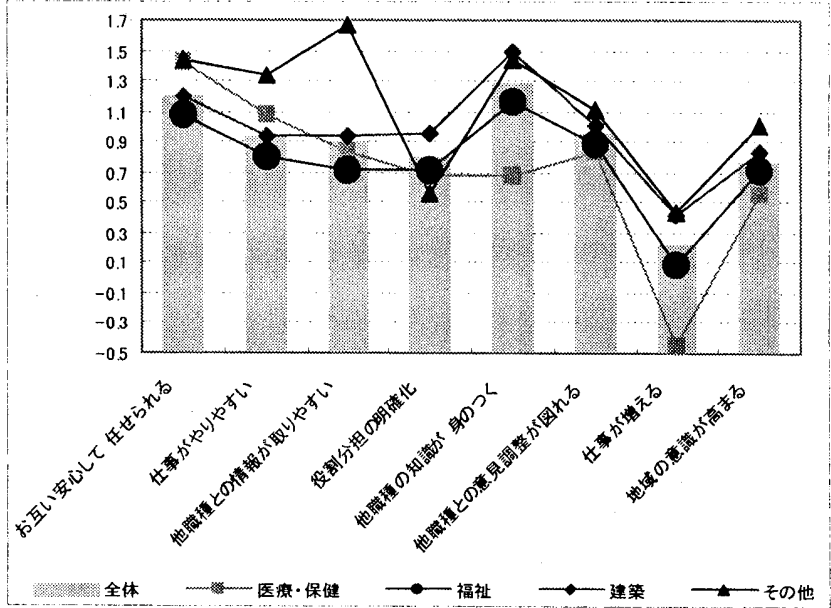

図 9 各職種の連携による効果

注）図8、図 92.0 : 非常にそう思う 1.0 : ややそう思う 0：どちらとも言えない -1.0 ：おまり思わない -2.0 ：全く思わない

表 5 各職種間の情報の流れ（最も情報を得やすい職種）

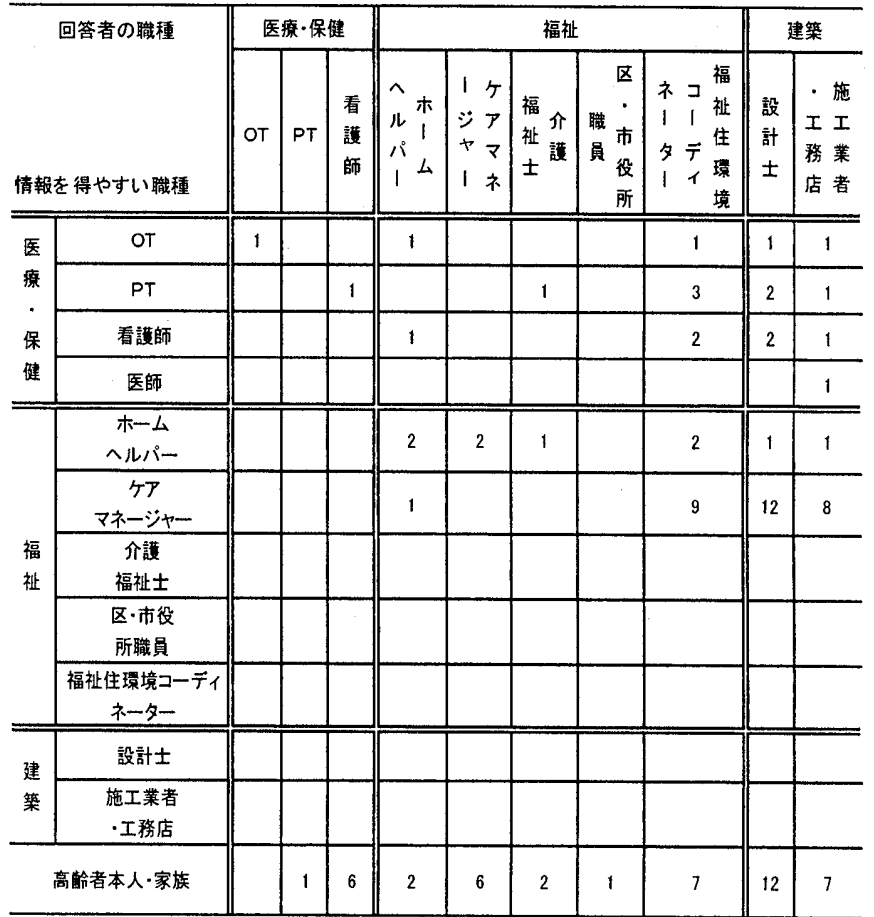


得やすい職種として「福祉」との回答が 22 人で最も多く、次 いで「高齢者本人・家族」に情報を得やすいと 19 人が回答し ている。福祉は、「高齢者本人・家族」に情報を得やすいとの 回答が 18 人で、同職種である「福祉」を 17 人が回答している。 また、PT、看護師、ホームヘルパー、ケアマネージャー、介護 福祉士、市役所職員、設計士が「高齢者本人・家族」に最も情 報を得やすいとの回答が最も多く、ほとんどの専門家は「高齢 者本人や家族」より高齢者の身体状況に関する情報を得やすい と思っていることが明らかになった。さらに、専門家間の情報 の流れとして、設計士は「ケアマネージャ一」に、福祉住環境 コーディネーターは「ケアマネージャー」、施工業者・工務店 は「ケアマネージャー」、ホームヘルパーは「ホームヘルパー」 に情報を得やすいと回答していた。以外にも、情報の流れは少 ないが、OTは「OT」、ケアマネージャーは「ホームヘルパー」に 情報を得やすいとの回答があった。専門家間の情報の流れで は、ケアマネージャーの活躍が著しくなっているが、これは介 護保険制度の開始後、連携でのケアマネージャーの活躍が増加 していることもあり、医療・保健・福祉・建築の連携に执いて ケアマネージャ一の役割がますます活発になると思われる。

\section{2 高齢者の身体状況に関する最も情報を得にくい職種}

高齢者の身体状況に関する最も情報を得にくい職種を表 6 に 示した。す心゙ての職種において、「医療・保健」が最も情報を 得にくいと回答しており、次いで、「福祉」である。さらに、専 門家別にみると医師や区・市役所職員が情報を得にくいと回答 している。このような傾向は、調査対象の組織に医師や区・市 役所職員の参加が少ないことが原因であると考えられる。実際 に、調査対象以外の組織にもこれらの専門家の参加は少ない。

\section{7 瞕種間の連携における意識}

\section{1 職種間の連携における問題意識度}

ここでは、職種間の連携をする上で、各職種により問題と されている事柄をサーストンの一対比較法注5)により順位付 けを試みた。その順位付けを各職種の連携による問題意識 度注6) と定義し、図 10 に示した。

一般的に連携での住宅改修は「a手間がかかる」と思われ るかちだが、ここでの「 いても最も低い結果であった。各職種の特徵としては、医 療・保健と建築では「 $\mathrm{e}$ 全体のケアが見えない」、福祉では $「 \mathrm{~d}$ 意見調整が難しい」の問題意識度が最も高く現われた。

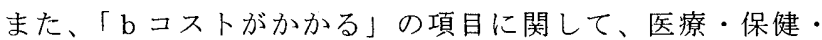
福祉では高い問題意識度を示している反面、建築では問題と して捉えなかった。

図 11 は、高齢者のための住宅改修の経験による問題意識度 を示したものであり、全体的に類似している結果をみせてい る。 $51 \sim 100$ 件以下の「а 手間がかかる」に対する問題意識 度は非常に低く、「e 全体のケアが見えない」は住宅改修の経 験に関わらず、最も高い問題意識度をみせた。

これらの結果をまとめると、職種間の連携での住宅改修は 各職種とも同様な問題を意識しており、その中でも「 $\mathrm{e}$ 全体 のケアが見えない」の問題に対して、強い意識度をみせてい
表 6 各職種間の情報の流れ（最も情報の得にくい職種）

\begin{tabular}{|c|c|c|c|c|c|c|c|c|c|c|c|}
\hline & 回答者の職種 & & 甞·保 & & & & 福祉 & & & & 聿築 \\
\hline & 得にくい瞕種 & ot & PT & $\begin{array}{l}\text { 看 } \\
\text { 護 } \\
\text { 師 }\end{array}$ & $\left\{\begin{array}{cc}\hat{A} \\
\text { ル } \\
\stackrel{1}{1} \\
1\end{array}\right.$ & 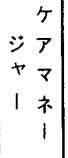 & $\begin{array}{l}\text { 福 } \\
\text { 祉 } \\
\pm \\
\pm\end{array}$ & 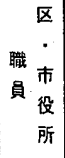 & 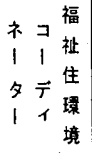 & $\begin{array}{l}\text { 設 } \\
\text { 竍 } \\
\text { 士 }\end{array}$ & $\begin{array}{l}\text { 施 } \\
\text { 工 I } \\
\text { 務 } \\
\text { 店 }\end{array}$ \\
\hline 医 & OT & & & & & & & & & & \\
\hline 療 & PT & & & & & & & & & & \\
\hline 保 & 看護師 & & & & & & & & & & \\
\hline 健 & 医師 & & & 5 & 1 & 1 & 1 & & 7 & 9 & 7 \\
\hline & $\begin{array}{l}\text { ホーム } \\
\text { ヘルパー } \\
\end{array}$ & & & & & & & & & & 1 \\
\hline & $\begin{array}{c}\text { ケア } \\
\text { マネージャー }\end{array}$ & & & & & & & & & 1 & 1 \\
\hline $\begin{array}{l}\text { 福 } \\
\text { 杫 }\end{array}$ & $\begin{array}{c}\text { 介護 } \\
\text { 福祉士 } \\
\end{array}$ & & & & & & & & & & \\
\hline & $\begin{array}{l}\text { 区・市役 } \\
\text { 邻職員 } \\
\end{array}$ & & 1 & 1 & 1 & 1 & 1 & & 2 & 2 & 2 \\
\hline & $\begin{array}{c}\text { 福杫住環境コーディ } \\
\text { ネーター } \\
\end{array}$ & & & & & & & & & & \\
\hline 建 & 設計士 & & & & & & & & & & \\
\hline 築 & $\begin{array}{l}\text { 施工業者 } \\
\text { ·工務店 } \\
\end{array}$ & & & 1 & & 1 & 1 & & & & \\
\hline & 高齢者本人·家族 & & & & & & & & 1 & 1 & 1 \\
\hline
\end{tabular}

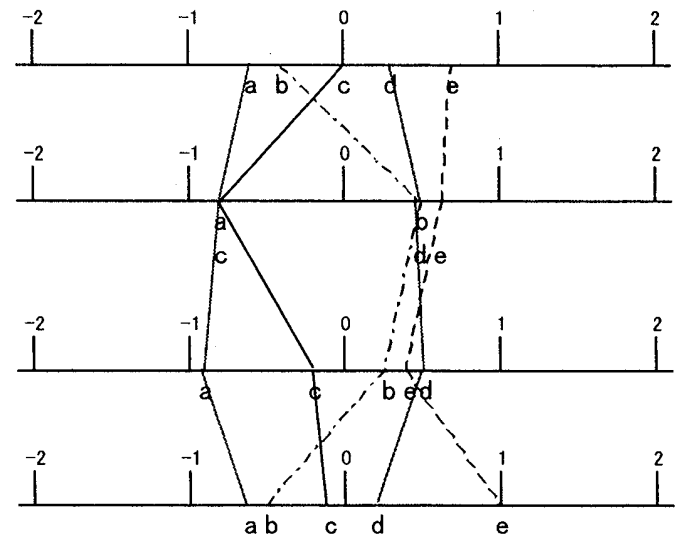

全体

医療 ·保健

福祉

建筑

a:手間がかかる b:コストがかかるc:分野のこだわり $\mathrm{d}$ :急兒調整が難しい e:全体のケアが見えない

図 10 職種の連携による問題意識度

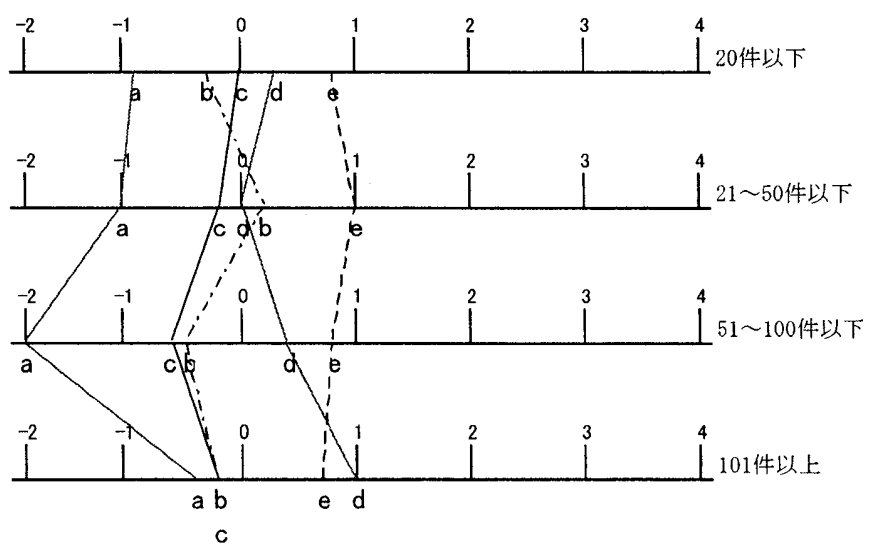

a:拳間がかかる b:コストがかかる : :分野のこだわり $\mathrm{d}:$ 意兒調整が難しい $\mathrm{c}$ :全体のケアが見えない

図 11 高齢者のための住宅改修の経験による問題意識度 
る。これらのことから、相互間の連携はしているものの、他 職種のケアには踏み込めないことが現状であることが推測さ れる。

\section{2 瞕種別の情報における重要意識度}

連携において職種別に重要とされている情報の考察を行い、 図12（職種別にみた情報における重要意識度注》）に示した。職 種別にみた情報における意識は、各職種とも類似しており、「d 高齢者の身体状況」が最も重要であると考えられていた。次に 「 f 過去の事例」を示し、過去の改修例に対する情報は各職種 において良い資料源として求められていることがわかる。ま た、他職種に比べ医療・保健での「d 高齢者の身体状況」を非 常に重視しているのが特徵であった。これら以外の情報に対し ては、それほどの重要性を示さなかった。

図 13 は、高齢者のための住宅改修の経験からみた情報にお ける重要意識度を示したもので、住宅改修経験による著しい差 はなく、「d 高齢者の身体状況」が最も高い重要度を示した。次 に、「f 過去の事例」を高く意識しておう、専門家は「 $\mathrm{d}$ 高齢者 の身体状況」や「 $\mathrm{f}$ 過去の事例」を重要な情報源として必要と していることがわかる。

\section{8 まとめと考察}

本調查の結果から、以下の 4 点が指摘できる。第一は、職種 の連携による専門家の参加活動や意識に関する特徴である。ま ず、参加の動機としては、「社会的な流れ」、「社会貢献のため」 が多く、介護保険制度とともに各職種の連携での参加も増えて いる。また、研究会の活動は職種間に相互関係を形成し、情報 交換や参考資料として、高齢者住宅改修に取り組む際に役に立 ち、ニーズへの対応になることがわかった。

第二は、職種の連携による効果や問題点に関する特徵であ る。まず、連携による効果としては、「お互いに安心して任せ られる」、「仕事がやりやすい」、「他職種の知識が身につく」な どの意識が高く、連携組織での活動が各職種にとって重要な役 割を果たしていることが明らかになった。次に、連携に対する 問題点としては、「全体のケアが見えない小、「意見調整が難し い」の意識が強く見られた。このような傾向は、職種間の理解 や職種別の明確な特徵を活かせていないという問題が未解決で あることを示している。また、医療・保健・福祉では、「コス トがかかる」との問題点の指摘が明らかになった。

第三に、高齢者の身体状況や生活スタイルに関する連携情報 の流れが重要であることが指摘できた。全体的には「高齢者本 人・家族」からの情報の流れが多く、職種間の連携による情報 の流れをまとめて図にすると、図 14 のように示すことができ る。また、専門家による情報の流れは、ケアマネージャーから 設計士・施工業者・福祉住環境コーディネーターに流れるケー スが多いことが明らかになった。

第四に、各職種が最も重要としている情報は、高齢者の「身 体状況」や「過去の事例」である。特に「高齢者の身体状況」 は、連携において最も基本的な情報であり、連携がスムーズに 行われるためには、これら情報が相手に正確に伝えることがで きる体制が必要である。また、良い改修事例を伝えることが、

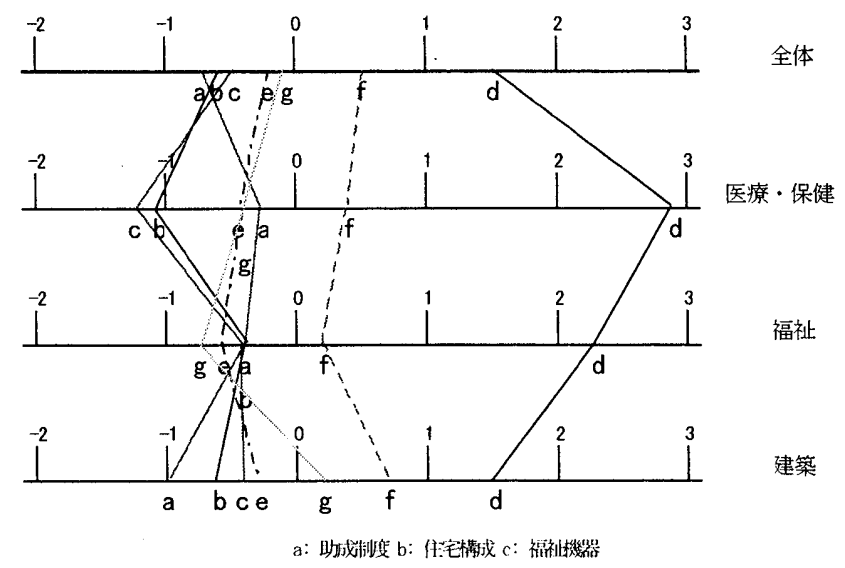

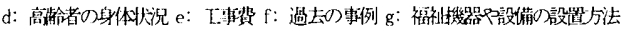

図 12 職種別にみた情報における重要意識度

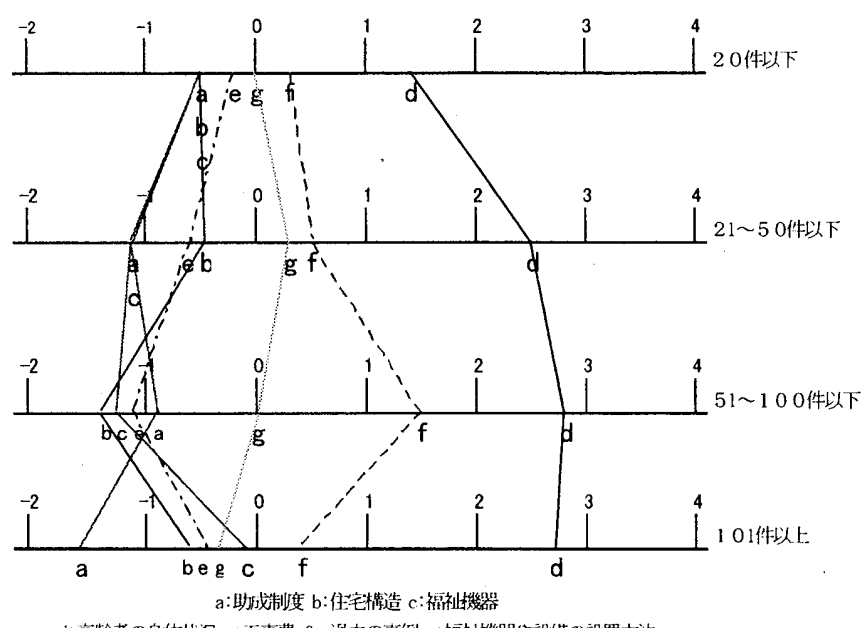

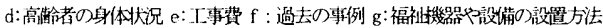

図 13 高齢者のための住宅改修の経験からみた情報における重要意識度

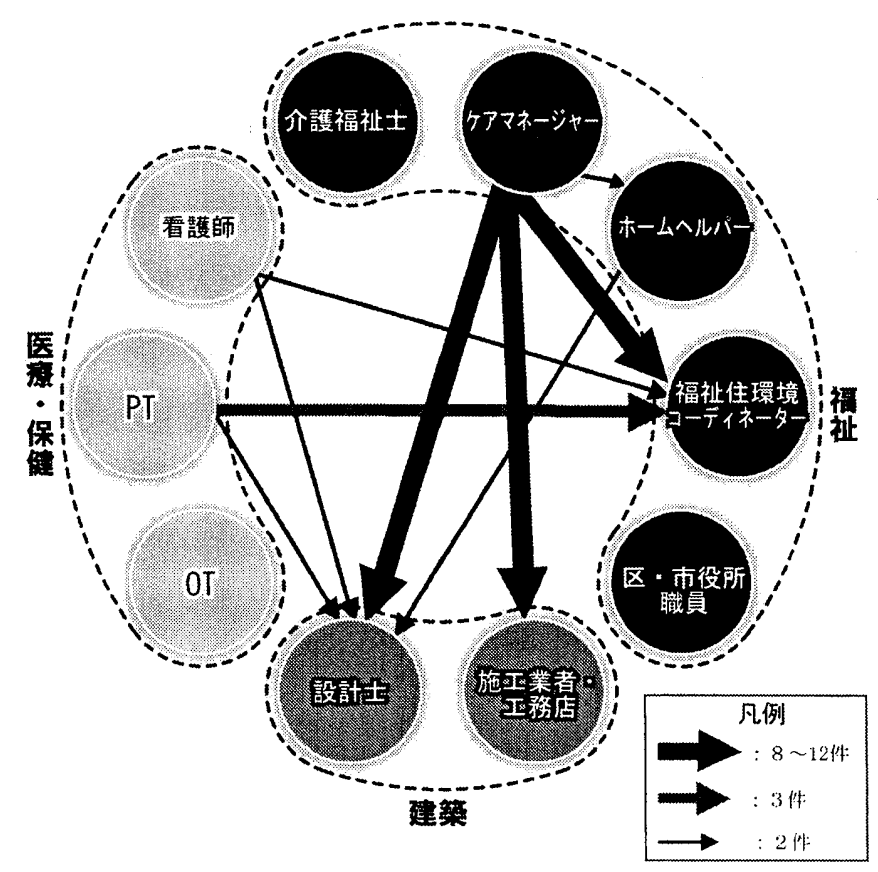

図 14 職種間の情報の流れ 注）線が太いほど情報が流れやすい 
良い改修に慗がると考えられる。

これらの結果から、職種の偏りを極力おさえ、多くの専門家 が参加することの有効性や連携での定期的なフォローアップ、 そして住宅改修後の状態把握は高齢者の自立生活のために重要 であることが指摘できる。また、今回の調査は、職種間連携の 未熟な段階における結果であり、実例を重ねていく上で、より 定量的な結果が必要と思われる。地域資源による違いなどの分 析も今後の課題としたい。

\section{謝辞}

今回の調查にご協力頂きました住宅改修連携組織・団体メンバーの皆様 に未筆ながら記して感謝の意を表します。

\section{注}

注 1 ）地域の高齢者の生活や住まい環境を支援するために医療・保健・福 祉・建築など、関連寸る職種・職能の専門家が連携して高齢者や障害者 をサポートする組織。

注 2 )「高齢者のための住宅改修」とは、高龄者が居住している一般住宅 の全般を示し、高龄者の身体状況や住み方にあわせて改修することを示 す。

注 3 ) 主として介護保険を利用した高龄者のための住宅改修に取り組んで いる専門家を示しており、OT、P T、看護師、ホームヘルパー、ケアマネ ジャ一、介護福祉士、区・市役所職員、福祉住環境コーディネーター、 設計士、施工業者・工務店として定義する。

注 4 ）近年、高齢者のための住宅改修に新しく福祉住環境コーディネー ターやケアマネージャーなどの職種が加えられ、これらの職業の住宅改 修はほとんどが介護保険関連の住宅改修である。

注 5）あらかじめ設定した項目（a〜 e、a $＼mathrm{~ g ~ ） の 中 か ら 組 み 合 わ せ の 異 ~}$ なる 2 つの刺激対を提示し、被験者にどちらかの方が問題と考えられる かあるいは重要と思われるかを選んでもらって、多くの刺激対の組み合 わせから各刺激の相対的位置を求め、各刺激の差を元に順序付け、尺度 化する方法。その手法による分析過程の例を表 7 に示寸。 注 6) 各専門家が意識している問題をサーストンの一対比較法を使い、算 出した得点を問題意識度として定義し、 $a, b, c, d, e$ の項目について、注 5) の手法による評価の結果 a 〜 e の重み付けを示した。数值が大きくな るほど問題を感じている度合いが大きいことを示す。

表 7 サーストン分析の導き手法（例）

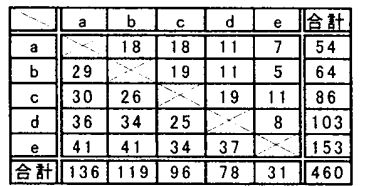

閶題意識度に対する判定集計

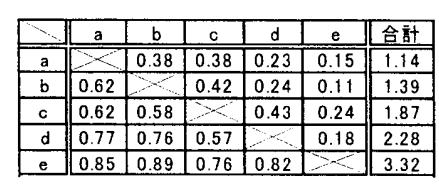

ii 標準正規分布表

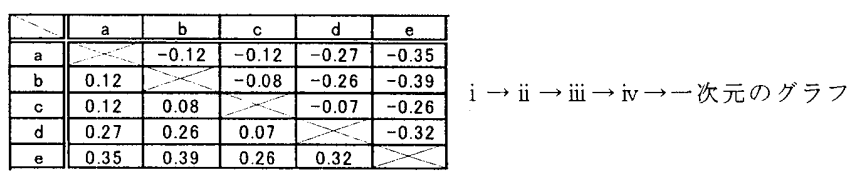

iii 摽淮正提分布表 -0.5

\begin{tabular}{|c||c|c|c|c|c||c|c|}
\hline & $a$ & $b$ & $c$ & $d$ & $e$ & 合㖕 & 得点 \\
\hline \hline $\mathrm{a}$ & - & -0.31 & -0.31 & -0.74 & -1.04 & -2.4 & -0.6 \\
\hline$b$ & 0.31 & - & -0.21 & -0.71 & -1.23 & -1.84 & -0.5 \\
\hline$c$ & 0.31 & 0.21 & - & -0.18 & -0.71 & -0.37 & -0.1 \\
\hline$d$ & 0.74 & 0.71 & 0.18 & -2 & -0.92 & 0.71 & 0.2 \\
\hline$e$ & 1.04 & 1.23 & 0.71 & 0.92 & - & 3.9 & 1.0 \\
\hline
\end{tabular}

iv 御点表 (合部 $\div 4$ (評伍物 $-1=4)$ )

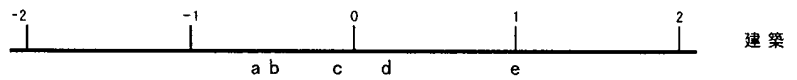

※注）上記の手法は建築分野に限る各職種の連携による問題意識度を例としてあげたもの である。
注 7 ) 各専門家が重要としている情報に対する意識を重要度として定義し $a, b, c, d, e, f, g$ にいて、注 6$)$ と同様に評洒を得た。

\section{参考文献}

1）林玉子他『バリア・フリー設計に関する建築関連職種の意識と対态 （その1）公共施設の設計に関寸る意識と対応の経年変化』日本建築学会 大会学術講演梗概集 $\mathrm{E}$ 分冊 pp. 331 332、1994.9

2）林悦子 他『バリア・フリー設計に関する建築関連職種の意識と対応 (その 2) 住宅改善におうる意識と対応』日本建築学会大会学術講演梗概 集 E分冊 pp. $333 \sim 334 、 1994.9$

3) 橋本 美芽 他『住宅改造における多職種の連携による指導の効果に関 する研究 (その3) 改造ニーズの類型化と専門職の関わり方』日本建築学 会大会学術講演梗概集 E-2 分冊 pp. 245 246、1995.8

4 ) 財団法人住宅総合研究財団高路者の寸まいゔくりシステム研究委員会 『ハウスアダプテーションー高齡者・障害者向け住宅改造・在宅ケアのシス テム化一』 1995

5 ）小滝一正他『東京都大田区に掞ける施工業者の関与の実態と意識 （その 4) 高澮者のための住宅改善に関寸る研究』日本建築学会大会学術 講演梗概集 E-2 分冊 pp. 173〜 174、1996.9

6 ）（財団法人）高龄者住宅財団『高路者のための住宅改造の寸すめ方』 1997

7 ）（財団法人）住宅総合研究財団 高齢者のすまいづくりシステム研究委 員会『在宅介護を考えるハウスアダプテーション用語集』2 000

8 ）（財団法人）高齢者住宅財団『高齢者のための住宅改造実態調査報告書』 2001

9）金 承喜 他『住宅改修におけるケアマネージャーの支援体制のあり 方に関する調查（その1）ケアマネージャーに負担を与える要因に関する 調査日本建築学会大会学術講演梗概集 F-1 分冊 pp. 1479 1480、2004.8 $10 ）$ 糟谷 佐紀 他『住宅改修におけるケアマネージャーの支援体制の あり方に関する調查（その2）住宅改修研修におけるケアマネージャーの 意識調査』日本建築学会大会学術講演梗概集 F-1 分冊 pp. 1481 1482、 2004.8

11 ) 巟玉 善郎 他『介護支援専門員の住宅改修への取り組みと意識に 関寸る研究 (その1）住宅改修八の取り組み実態』日本建築学会大会学 術講演梗概集 E-2 分冊 pp. $295 \sim 296 、 2004.8$

12 ) 岡部 真智子 他『介護支援専門員の住宅改修への取り組みと意識 に関する研究 (その2) 住宅改修に対する意識』日本建築学会大会学術 講演梗概集 E-2 分冊 pp. $297 \sim 298 、 2004.8$

(2006年 7 月 10 日原稿受理，2007年 4 月10日採用決定） 